\begin{tabular}{|l|l|l||}
\hline \multicolumn{2}{|c|}{ PublisherInfo } \\
\hline \hline PublisherName & $:$ & BioMed Central \\
\hline \hline PublisherLocation & $:$ & London \\
\hline \hline PublisherImprintName & $:$ & BioMed Central \\
\hline \hline
\end{tabular}

\title{
Parasites bare all
}

\begin{tabular}{||l|l|l||}
\hline \multicolumn{2}{|c|}{ ArticleInfo } \\
\hline \hline ArticleID & $:$ & 4262 \\
\hline \hline ArticleDOI & $:$ & $10.1186 /$ gb-spotlight-20011126-02 \\
\hline \hline ArticleCitationID & $:$ & spotlight-20011126-02 \\
\hline \hline ArticleSequenceNumber & $:$ & 333 \\
\hline \hline ArticleCategory & $:$ & Research news \\
\hline \hline ArticleFirstPage & $:$ & 1 \\
\hline \hline ArticleLastPage & $:$ & 2 \\
\hline \hline & & RegistrationDate : 2001-11-26 \\
ArticleHistory & $:$ & OnlineDate $\quad$ 2001-11-26 \\
\hline \hline ArticleCopyright & $:$ & BioMed Central Ltd2001 \\
\hline \hline ArticleGrants & $:$ & \\
\hline \hline ArticleContext & $:$ & 130592211 \\
\hline \hline
\end{tabular}




\section{David Bruce}

Email: davidb@biomedcentral.com

The very nature of the parasitic lifestyle enables parasites to substantially reduce the size of their genome. In 22 November Nature, Michaël Katanika and colleagues at Genoscope describe the genome of the microsporidian parasite Encephalitozoon cuniculi, which seems to have taken this reduction process to the very limit (Nature 2001, 414:450-453.).

The $2.9 \mathrm{Mb}$ E. cuniculi genome consists of 11 chromosomes with 1,997 potential protein coding sequences tightly packed together with little 'junk' DNA in between. It has long been thought that the microsporidia diverged evolutionarily before the development of mitochondria, as these organelles are absent from the cytoplasm of the parasite. But, with the completion of the genome sequence five proteins classically associated with Fe-S cluster assembly machinery - an essential function of mitochondria - have been identified. It is still unclear if these genes have relocated to a site within the cytoplasm or exist in a residual mitochondrion-derived organelle such as the 'mitosome' recently described in Entamoeba histolytica.

Katanika et al. suggest that this work could provide a useful reference in the comparative genomics of microbial eukaryotes. It may be of particular importance in identifying the relative importance of shared genes in the parasites that cause major human diseases such as Plasmodium and Leishamnia.

In an accompanying News and Views article, Patrick Keeling of the Department of Botany, University of British Columbia, said, "This is an exciting time for parasitology, and if E. cuniculi is an honest herald, many 'rules' are about to be broken."

\section{References}

\section{Nature, [http://www.nature.com/]}

2. Genoscope, [http://www.genoscope.cns.fr/]

3. Katinka MD, Duprat S, Cornillot E, Metenier G, Thomarat F, Prensier G, Barbe V, Peyretaillade E, Brottier P, Wincker P, et al:: Genome sequence and gene compaction of the eukaryote parasite Encephalitozoon cuniculi. Nature 2001, 414:450-453., [http://www.nature.com/cgi-taf/ DynaPage.taf?file=/nature/journal/v414/n6862/abs/414450a0_fs.html]

4. Keeling PJ: Parasites go the full monty. Nature 2001, 414:401-402., [http://www.nature.com/cgi-taf/ DynaPage.taf?file $=/$ nature/journal/v414/n6862/full/414401a0_fs.html]

5. Department of Botany, University of British Columbia, [http://www.botany.ubc.ca/] 